\title{
Routines Disrupted: Reestablishing Security through Practice Alignment
}

Marcus Phipps

Julie L. Ozanne

Marcus Phipps is a Lecturer at the Department of Management and Marketing, University of Melbourne, 198 Berkeley Street, Melbourne VIC 3010, mphipps@unimelb.edu.au. Julie L. Ozanne is a Professor at the Department of Management and Marketing, University of Melbourne, 198 Berkeley Street, Melbourne VIC 3010, julie.ozanne@unimelb.edu.au. The authors would like to thank Robin Canniford, Terry Cobb, and Bige Saatcioglu for their very helpful comments on earlier versions of this manuscript. The authors also thank the three reviewers, associate editor, and editor for their very supportive comments throughout the review process. 


\begin{abstract}
Routines are the taken-for-granted practices that form the rhythm of everyday life making people feel secure. How do consumers manage when their routines are disrupted? Practice theorists assert that practices are important to understanding consumption and stress their shared, repetitive, and conventional nature. When practices are stable, they are performed effortlessly producing feelings of ease and trust in a predictable world. People are often unaware of the embodied competencies, or practical understandings, involved in the performance of these practices. However, practical understandings become apparent when elements of practices are misaligned. Our findings advance Gidden's (1984) theorization of ontological security by showing how the interplay between practical and discursive understandings and material configurations works to produce different ontological states that we call embedded security, embedded insecurity, discursive insecurity, acclimating security, and new embedded security. We also show how households subtly rework the underlying constitutive rules that anchor important practices in place within practice alignment.
\end{abstract}

Keywords: routines, practice theory, ontological security, constitutive rule, practical understanding, obdurate materiality. 
Routines are an ever-present part of ordinary life. Consumers' lives are composed of countless routines making up the "barely detectable gridlines of everyday life” (Shove 2003a, 3). Consumers wake up to the dependable ring of their alarm clocks. Tightly scripted routines of cleanliness, convenience, and comfort are facilitated by running the dishwasher, doing the laundry, or taking a shower (Shove 2003a). Consumers shop at the same grocery stores and purchase a similar array of goods. Even an innovation like the iPhone is successful, in part, because of the ease at which consumers integrate the technology into their daily routines when talking to family and friends, planning social events, or shopping.

The taken-for-granted nature of these routines is rarely contemplated by consumersuntil these routines are disrupted. Thus, it is unsettling when a storm brings down electrical lines and there is no light, warmth, or entertainment. It is unsettling to turn on the kitchen faucet only to find it dry. It is unsettling to walk into a grocery store and see shelves laid bare. It is unsettling to find one's cell phone does not work and to feel unmoored from countless daily routines.

Our focal research question is how do consumers adjust to this unease arising when their normal routines are disrupted? This research draws from Gidden’s (1984) conceptualization of ontological states of security that theorizes the importance of consumers' everyday routines. He defines ontological security as the deep-seated trust people have that their world is secure and predictable. Ontological security begets "an autonomy of bodily control within predictable routines" and people "feel at home with themselves" and in the world (Giddens 1984, 50; Thompson 2005).

We also draw on practice theory to help explain what happens when routines are disrupted. Practice theory draws attention to practices as an important concept for ordering social life and consumption (Schau, Muñiz, and Arnould 2009). Although a diversity of practice theories exists, most theorists would agree that practices are human activities that are 
embodied, mediated by material configurations, and “organized around shared practical understandings” (Schatzki 2001, 11; emphasis added). Schatzki (2001) explains the smooth and easy performance of practices by theorizing an embodied but unarticulated sensibility or what he calls a practical understanding. In Bourdieu's $(1977,1984)$ theory of practice, the concept of habitus similarly captures an embodied practical understanding or "practical sense." Drawing on this theory, consumer researchers talk about how this "feel for the game" underlies working-class students' selection of higher educational institutions that "fit-like-aglove” and just feel right (Allen 2002).

Most consumer and practice theorists assume these "practical understandings” are embodied, learned over time, and drawn upon instantly with little deliberation (Bourdieu 1984; Giddens 1979). Arsel and Thompson (2011, 804) argue that these "habituated predispositions” are not easily shed "because they are integrated into the practices through which consumers materially, affectively, aesthetically, and intellectually relate to the social world.” Routine practices enact practical understandings helping consumers feel comfortable in the seamless performance of their ordered lives. People feel safe within the predictable flow of these shared routines that are "structures of time" (Wilk 2009, 147).

But what happens when routines are disturbed? How are different ontological states enabled within practice realignment? How does the material configuration both facilitate ontological states of security and insecurity? Why are some practices more important for achieving ontological states of security? These are the questions that this research sets out to answer. Our research context is the twelve-year drought in Australia where countless routines were disrupted. But first, we set the stage for the study by delving into definitions of ontological states of security and prior theorizations of practical and discursive understandings. 


\section{THEORETICAL FOUNDATIONS}

\section{Ontological State of Security}

Anthony Giddens (1984) contends that people have an unconscious need to feel existentially secure. People are secure when they feel a sense of order and predictability about their place in the world (Giddens 1991; Thompson 2005). According to the developmental work of Erik Erikson, children who are reliably cared for by a mother or caregiver develop a generalized trust in the world. This generalized trust is reenacted within familiar routines that develops a sense of security.

For Giddens, the drive for ontological security, in part, urges peoples’ monitoring and reproducing of routines anchored in time and place. Anxiety is managed within daily routines, such as waking at the same time, having coffee, reading the daily newspaper, and walking in the garden (Cassell 1993). The routines of daily life within the home are particularly important because they help people feel secure and keep at bay the chaos that threatens to overwhelm them (Dupuis and Thorns 1998). "Routinization is vital to the psychological mechanisms whereby a sense of trust or ontological security is sustained in the daily activities of social life (Giddens 1984, xxiii).”

Harold Garfinkel (1967) provides some of the most compelling explorations of the rudimentary practices that maintain social life. His inquiry focused on the invisible but background understandings that people use to locally produce and make social life intelligible. This research exposed the significant emotional investment that these routines hold for individuals. Garfinkel used breaching experiments that created anomalies incongruent with common expectations: his students acted as boarders to their families in their own homes, they broke the shared rules of the game of tic-tac-toe, or they insisted in conversation that their friends clarify widely understood phrases (Garfinkel 1967). These 
breaches in the common practices of performing social life instantly made the other social actors feel disoriented and anxious: “On the other side of what might appear to be quite trivial aspects of day-to-day action and discourse, chaos lurks” (Giddens 1991, 36). These breaching experiments reveal the significant emotional investment people have in restoring the routine practices that allow for the smooth production of social life.

To further understand why feeling secure matters, we outline the discursive and practical forms of consciousness that co-constitute ontological states of security. It is during times of ontological insecurity that the distinction between practical and discursive consciousness are more apparent and states of security become more available for scrutiny.

\section{Discursive and Practical Consciousness}

Many consumer researchers employ methods, such as interviews, to capture consumers' accounts for their actions. These discursive accounts are then widely used to understand actions, such as how consumers select universities (Allen 2002), decorate their apartments (Arsel and Bean 2013), or veil fashionably (Sandikci and Ger 2010), to name but a few. Within Giddens’ framework, these consumer accounts are defined as discursive consciousness — the deliberate ability to give rational accounts for one’s actions. But discursive consciousness is just the tip of the iceberg under which rests practical consciousness and ontological states (Giddens 1979).

Practical consciousness is the "tacit knowledge that is skilfully [sic] applied in the enactment of conduct, but which the actor is not able to formulate discursively (Giddens 1979, 57, emphasis added).” Giddens suggested that when social actors give discursive accounts for their behavior, they draw on "the same stocks of knowledge” used when they enact their behavior. Thus, practical consciousness captures this gap between what can be 
articulated and what tacitly guides behavior. For Giddens, feelings of existential security or anxiety lie beneath practical and discursive consciousness.

But Giddens inadequately develops the physical embodiment upon which practical consciousness rests. Next, we draw upon Michael Polanyi’s concept of tacit knowledge. We round out this discussion by drawing on Theodore Schatzki's explanation of how practical and discursive understandings occur within different forms of social life. To avoid confusion regarding the meaning of individual consciousness, we now employ Schatzki’s termspractical and discursive understanding — to emphasize that these are shared understandings within practices.

\section{Practical Understandings}

Untangling Forgotten Conventions and Embodied Understandings. Practices, such as recognizing a familiar face, riding a bicycle, diagnosing an illness, and selecting a university, all draw on particularities that people cannot necessarily articulate. Two notions are important here. First, these unspoken understandings may be widely shared conventions, learned and then forgotten, which makes them difficult to articulate (Polanyi 1966). Within the home, daily routines are based on conventions of comfort, cleanliness, and convenience; although these forgotten conventions may not be readily available, it is possible to discuss them (Shove 2003abc). These conventions may also be observable (e.g., the nonverbal cues exchanged between a bicyclist and driver when coordinating joint actions, such as yielding within an intersection).

Second, these unspoken understandings may be embodied and not necessarily articulable (e.g., balancing on a bicycle). For example, Polanyi $(1966,4)$ used the concept of “tacit knowledge,” where “we can know more than we can tell.” Drawing on Gilbert Ryle’s distinction between "knowing what" and "knowing how," Polanyi suggests our bodies are the 
ultimate source of this knowing. The tacit knowing of a tool is "the transformation of the tool or probe into a sentient extension of our body" (1966, 16, emphasis added). It is the feel of the wrench-in-hand and the subtle distinction between tightening a bolt, just enough, but not too much. In this sense, tacit knowledge is embodied, whereas conventional meanings are disembodied because they can be expounded upon and codified; thus, practices rest on both embodied and conventional knowledge (Polanyi 1966). Theodore Schatzki builds on this idea but conceptualizes these elements as more tightly integrated within conditions of social life.

Practical Understandings within Conditions of Life. For Schatzki (2002, 72), “practices are open, temporally unfolding nexuses of actions.” Most basically, practices comprise things people do with their bodies_-bodily doings and sayings—-turning knobs, issuing commands, or raising eyebrows. These activities cohere to form practices. We follow Schatzki's Wittgensteinian approach that practical understanding does not determine what people do. He conceptualizes mental events from a more social perspective. Mental states are “conditions of life,” "how-it-is,” or "how things stand and are going for someone.”

So an activity does not express a given condition by virtue of being its effect. It does so instead, as we shall see, by virtue of its place in the weave of behaviors and of occasions and contexts of behaviour... So there is nothing theoretical about "mental state" talk, and its explanatory powers are not tied to the operations of an underlying apparatus. Instead, such talk is the shared, original, medium of the everyday explicit understanding a person has of herself and others (Schatzki 1996, 23-24).

Therefore a mental state does not necessarily precede these doings and sayings (it may or may not). What is important for studying social life is that mental states are more directly enacted in social practices. Woermann and Rokka (2015) also demonstrate this idea in their study of timeflow. The authors note that consumers may happily lie on a beach for hours without noting the time, yet they may become frustrated and impatient after mere minutes of waiting in line. It is not a mental state that directly causes these contrasting experiences of temporality; rather the contrast emerges by virtue of the practice's place in the 
weave and social context of the behaviors. Beach goers may be relaxing on holidays, while the person waiting in line may be juggling many activities.

Practical understanding is “knowing how to go on” (Wittgenstein 1958, I, no. 875). Thus, practical understanding becomes more accessible for study by both the practitioner and a knowledgeable observer as they are shared understandings (Reckwitz 2002; Schatzki 2002). In our context of a drought, countless routines were disrupted and it was not always clear "how to go on.” Within this pulling apart and then putting together of many routines, we observed the interplay among ontological states and practical and discursive understandings. Moreover, a constitutive rule emerged playing an important part in re-anchoring routines of security. Therefore, in the last section of our theoretical introduction, we explore how constitutive rules can anchor practical and discursive understandings making some practices more important.

Practical Understandings and Constitutive Rules. Not all practices are equal. Some practices are deeper and more enduring and shape other practices. For example, owning a home is a practice that is connected to many other practices and, thus is more fundamental and pervasive than, say, the practice of cooking in a convection oven (Swidler 2001). In addition, some practices are important because they form constitutive rules in the sense that they are definitive, in the way that a marriage ceremony is a practice that defines what it means to be married (Searle 1995).

Practices can also anchor and then reproduce the constitutive rule it expresses. "The Lesbian/Gay Freedom Day Parade is a public ritual practice, one that enacts, without explicitly describing, the nature of the community it creates (Swidler 2001, 92).” Gay pride parades sanction diversity and then reproduce diversity as a defining element of the gay community. Similarly, the Western idea that people are autonomous and independent individuals is constituted by practices, such as calling a person by name, taking turns in 
conversations, looking at them directly in the eyes, respecting their space and possessions, and so on.

In another example that is particularly relevant for our purposes, Swidler (2001) argues that voluntarism acts as a constitutive rule structuring many spheres of American life. Groups are formed by the voluntary choices of individuals seeking to satisfy their interests.

Thus when American children choose group activities, or when schools encourage after-school clubs, or when Americans join a church and pay dues, as when on important civic occasions they celebrate 'freedom,' they participate in ritual practices that reinforce voluntarist individualism. This pattern is resilient... [and] provides the 'default option' for organizing collective action (2001, 99).

Voluntarism plays out in practices as innocuous as being friendly that mutually reinforce the rule. American practices of friendliness reproduce the freedom to choose group life where people need to get along and conflict could threaten civic life upon which voluntarism depends. This enables societal cohesion goals such as the quest for community to exist alongside the assertion of individualism that is core to American social life.

In the next section, we explore the constitutive rule of egalitarian individualism found in many spheres of Australian life, as well as the methodology and context of the study. We examined households who transitioned from an ontological state of security to insecurity during a persistent drought in Australia. This context provided an ideal setting for our purposes because a wide range of conventional routines were unsettled exposing both practical and discursive understandings and their interplay. This section is followed by our empirical findings on how practical and discursive understandings anchor different ontological states: embedded security, embedded insecurity, discursive insecurity, acclimating security, and new embedded security. We find different patterns where some household's insecurity is actually anchored to materiality. But we also see households stuck in states of discursive insecurity while other households moved through this state to restore security to varying degrees. 


\section{RESEARCH PROCEDURES}

\section{Research Context}

Periods of decreased rainfall are recurrent in Australia, but the 1997 to 2009 drought was the most significant and long-lasting ever recorded. In 2007, records were broken, including having the driest year ever recorded and the lowest reservoir levels (Australian Bureau of Meteorology 2007; “Big Dry Breaks Record” 2007; “Drought Proof Dam Hits Record Low Level” 2007). During 2005-2008, state authorities instituted permanent watersaving measures and gradually introduced water policy restrictions. Regulations limited garden watering to a two-hour period twice weekly (i.e., $6-8$ am for manual watering; $12-2$ am for automatic watering), and automatic watering was restricted to drip-feed systems. The state government introduced a tiered pricing system encouraging all Melbourne residents to restrict water consumption by penalizing excessive use.

Data collection spanned 2007-2008 during the peak of the drought. The severe drought and policy restrictions led to disruptions in wide ranging routines involving water. People reduced their overall water consumption, and these collective reductions persisted into 2011 when the drought ended and restrictions were lifted. In 2012-2013, the average water use was 161 liters per person, 35\% less than four years into the drought and 62\% less than the average consumption throughout the 1990s (Wear 2015). During the peak of the drought, the issue of water scarcity was at the forefront of the public's attention, inspiring widespread discussions (Phipps and Brace-Govan 2011). Daily weather reports updated the city’s dwindling water supply. Newspapers regularly announced record-breaking statistics and printed water-supply changes on their front pages. Reductions in water use were initiated as a result of a combination of severe crisis, public discussions, and government policies and restrictions on household water usage. 


\section{Research Households and Data Collection Methods}

Initial entry into the field occurred during a public tour of a house that was independent from city water. The lead researcher participated in this tour with 20 other interested consumers. Informal discussions with tour participants led to subsequent interviews being scheduled with them. Many of these informants suggested other potential participants. Thus, households were initially recruited through snowball sampling (see table 1). Households were then purposefully sampled based on the extensiveness of changes in their water use routines. Participants ranged from households where only modest changes were made, such as reusing gray water, to households that reformulated many of their practices, even becoming independent from the city water supply through creating new grayand rainwater systems. (Gray water is household water that is reused for a second purpose, such as shower water that is collected and reused to flush a toilet; rainwater systems involve the collection of rain to supplement household supply, such as the use of rainwater tanks to collect water for gardens.)

\section{[Insert table 1 here]}

All interviews were conducted at the informants' homes so the lead researcher could observe physical changes to the house, such as the installation and use of new water systems. Interviews ranged from one to four hours with most lasting about two hours. Data were collected through recorded in-depth interviews, field notes, and photographs taken during a home tour with each interviewee. A semi-structured interview focused on participants taking the researcher through a typical day of using water within their households. Subsequent probes explored blocked practices, as well as changes in meanings and competencies around practices using water. Secondary data were also collected from government reports, newspaper articles, and online blogs. 


\section{Data Analysis}

The analysis focused on understanding routines that used water and their meaning. We examined routines through an analysis of all textual data, including coded interviews, field notes, photographs, and secondary data. Our focus was on the nature of the household changes, new practices and materials used, and shifting meanings and competencies. An important element of this analysis was identifying the difference and relationship between practical and discursive understandings. This required paying attention to what Woermann (forthcoming) refers to as the "situational setup.” When situational order breaks down, it provides an effective way to access practical understandings (Hill, Canniford, and Mol 2014). The severe drought disrupted daily household routines and brought into foreground many forgotten conventions that were not normally discursively available in interviews (Shove 2003b; Shove, Pantzar, and Watson 2012). Although not directly interrogated, informants volunteered their feelings of unease providing empirical support for our theorization.

During unsettled times, particularly when people are engaging in unfamiliar practices, constitutive rules may become more available for discursive understanding (Swidler 1986). In this study, many routines were unsettled by persistent water shortages and people rethought countless routines. As Australians reworked these disrupted routines, the concept of "mateship" emerged as a constitutive rule of citizenship. We briefly explore the notion of mateship to understand its cultural meaning and provide socio-historical context. Mateship as a constitutive rule of being Australian is linked to such wide ranging practices as the informal use of first names in professional settings, the distaste for status markers even among elite consumers (Turner and Edmunds 2002), Australian and New Zealand Army Corps celebrations (Kapferer 2011), military interventions (McDonald 2010), and citizenship tests (Tavan 2009), to name but a few examples. We do not intend to totalize Australian identity, 
but rather present mateship as a constitutive rule of citizenship that paradoxically provides both stability and flexibility in the reestablishment of routines.

\section{Mateship as a Constitutive Rule}

Mateship is commonly evoked as an iconic symbol of Australian identity (Page 2002). It is an expression of both mutual independence and social solidarity "where the tenets of loyalty, non-pretentiousness and stoicism combine with the ideals of fairness, selfsufficiency and egalitarianism” (Butera 2008, 265; Kapferer 2011). Consider the practice of Australian pub drinking among a group of friends. Every group member, regardless of social status or income, pays for a shout (or round) of drinks. "Mates" continue drinking together until everyone has had a shout; it is poor form to depart early or fall behind, and drinking alone is even described as “ontologically threatening” (Kapferer 2011, 159-60). This practice enacts a balance affirming individual autonomy to buy a shout and continue drinking while affirming social solidarity among equals.

But mateship is a constitutive rule of citizenship visible in contemporary social practices in Australia. It is "the way society forms, independent of artificial mediating institutions such as those implicit in the concept of the state” (Kapferer 2011, 344). An egalitarian individual ideology lies at the very heart of Australian nationalism. Like all colonial states, Australia was formed through the institutions and practices of the colonizer, in this case, the British, who proclaimed the land as having no prior sovereignty. The creation of the Australian colonial state was an extreme case of "an absolutist state and a disciplinary society...a complete construction of the state” (Kapferer and Morris 2006, 252).

For example, the Australian "pioneer legend” stands in discursive opposition to the historical foundations of elitist colonial rulers centralizing power within urban areas. Pioneers had small holdings in the bush and rural areas where many settlers first lived. They battled 
shoulder-to-shoulder with their laborers in this hostile environment, fighting against fires, floods, and droughts. The pioneer legend recalls individuals persevering by coming together for mutual aid and working across class lines. Thus, this Australian idea of mateship has a deep history originally arising from resistance against class divisions and conflicts in British society and affirmation of self-sufficiency (Butera 2008; Kapferer and Morris 2006). Anchoring practices that arise amid conflict and antagonism strengthen the constitutive rule, making it more resilient, such as defining Australian individual egalitarianism against British elitism (Swidler 2001). Today, ubiquitous social practices, like Australians sitting in the front seat of a taxi next to their driver, affirm individual egalitarianism anchoring the constitutive rule and supporting discourses.

Next, we turn to our findings on how ontological states of insecurity were differently refigured within disrupted routines. We also explore how the constitutive rule of egalitarian individualism was affirmed by flexibly reworking this idea within these new routines.

\section{ADJUSTING PRACTICES WITHIN ONTOLOGICAL STATES}

We structure our findings around the five different ontological states that emerged from our research. Prior to the drought, all of the households were in an ontological state of security as routines were embedded into obdurate materiality creating a sense of a predictable and stable present and future. We define the durable material infrastructure, such as the relatively-fixed electrical or plumbing grid work, as obdurate materiality (see also Shove et al. 2012, 47). First, we turn our attention to explaining the state of embedded security where household routines around water fit and cohered within a larger water infrastructure. Using secondary data, we explore when household routines are aligned and stable in invisible urban mains, as was the case for all Australian households before the drought. 
For all of the households studied, their ontological state shifted to varying degrees of insecurity following the drought and water restrictions. We trace how this ontological state of insecurity shifts practical and discursive understandings and the eventual realignment of households' practices. As this insecurity breaches practical and discursive understandings in aligned practices, four general ontological states emerge across different households: embedded insecurity where households continued to feel uneasy as practices were rooted in obdurate materiality and blocked; discursive insecurity where some households continued to feel insecure as practices were fragile across repeated failed attempts at deliberation and realignment; acclimated security where some households achieved a greater sense of ease and predictability as practices were attuned, refined, and reworked within new material configurations; and new embedded security where some households returned to feelings of generalized trust and new routines that were stable and fully anchored. Table 2 provides the general conceptual underpinnings of the different ontological states as households attempt to return to practical and discursive understandings that were more automatic and unreflective.

[Insert table 2 here]

\section{Embedded Security}

Domesticity is reproduced in the home through practices creating conventional meanings of comfort, order, and efficiency (Dion, Sabri, and Guillard 2014). The convenient and easy cleaning of homes, bodies, and possessions depends on a material configuration of cheap and abundant water (Shove and Warde 2002). Consumers are connected to this system through invisible plumbing within the home connecting to relatively stable fixtures of sinks, toilets, and showers, as well as infrequently replaced appliances like washing machines and dishwashers. This material configuration allows practices to align effortlessly and for people 
to feel a deeply embedded sense of security; alternative options do not make sense, nor do they even arise for discursive reflection (see table 2, Embedded Security).

Performing intimate everyday practices, such as brushing teeth or bathing, is like following the worn grooves in a street and provides a "bubble of inattention" that can produce an almost meditative quality (Wilk 2009, 149; Woermann and Rokka 2015). Routines employing water generally rely upon these kinds of practical understandings. The competencies needed to do laundry, bathe, flush a toilet, or water the garden are embodied and well-practiced, and people feel secure enacting their routine practices. Typically households do not reflect on these practices because they are experts at washing, cleaning, showering, and maintaining the yard. These practices require embodied skills, such as turning on a faucet or flushing a toilet (Shove and Warde 2002). The tools are indeed "sentient extensions” of the hand (Polanyi 1966, 16).

Discursive understandings of mundane practices remain within taken-for-granted and implicit meanings, such as cleanliness or hygiene. Modest deliberation might occur on questions, such as which laundry rinse works best to clean soiled clothes or how much water is needed to make my grass green? This limited reflection means practices are smoothly produced and reproduced enacting convenience, cleanliness, comfort, and order.

Conditions of use "are prescribed largely by the technologies themselves” (Shove 2003c, 195) and is part of this fixed material infrastructure that we call obdurate materiality. This obdurate materiality both facilitates stability of current practices but poses some obstacles for the free circulation of practices. For example, these routines are so scripted that "washing the dishes” means using a dishwasher and is tightly linked to social meanings of convenience. “Bathing” means taking a daily shower, splashing water, and lathering up a bar of soap to produce cleanliness (Shove 2003b). Reflection is not only unnecessary but may 
even be unwelcomed given the widely accepted and efficient practical understandings that facilitate the smooth running of a household (Thompson 1996).

The aligned practices of domesticity tied to obdurate materiality are found in Australia as well. Moreover, the practice of homeownership is an important enactment of the constitutive rule of egalitarian individualism where everyone has a fair shot at homeownership (Colic-Peisker and Johnson 2010). Unsurprisingly, many suburban homes are equally modest and sited on similar-sized lots, offering households a common material configuration for home practices to be enacted. The Australian "suburban bungalow, with its generous backyard, came to occupy a place of pride in popular versions of good society” (Badcock 2000, 254). Mateship was enacted prior to the drought in maintenance practices, such as keeping up the tidy appearances of the home and nurturing a fecund yard and garden as a source of neighborhood pride. Australians take a do-it-yourself approach to maintaining their homes and enact self-sufficiency within these and other home practices (Thomson 1998).

\section{Ontological State of Insecurity Across all Households}

All of the households studied were in ontological states of insecurity to varying degrees as the drought persisted and became more severe. This finding was evident within all interviews. For example, Hannah captures how an embodied unease begins to pierce practical understandings that were once silent: "You get really nervous about it so if I see someone with a tap running, I just have to absolutely hold myself back not to go and turn it off.”

Again, all households first struggled to maintain existing everyday routines by being tactical and making minor adjustments, such as using easily available materials and leveraging competencies at hand. Consumers used new materials, such as bricks to place in toilet cisterns, buckets for retrieving water, and tubing to redirect laundry rinse. They also 
turned off water taps, took shorter showers, did laundry less frequently, hand-washed dishes, and hauled gray water. Table 3 summarizes the most common old and new practices and how households tried to adjust competencies, materials, and meanings. But the obdurate materiality of urban mains, which once invisibly and comfortably connected households to abundant water, was now problematic.

\section{[Insert table 3—Practice Realignment]}

Some practices were dropped, like watering lawns, washing cars, maintaining swimming pools, and some gardening practices (see table 3 and broken links). People let their lawns die, a public practice enacting mateship as a shared sacrifice for the common good. Most households privately stopped using their dishwashers and reformulated the practice of hand-washing dishes to use less water. New meanings emerged. Cleanliness was delayed and greater domestic disorder accepted as dishes piled up in the sink-all to preserve water. Waste water, which once went down shower and laundry drains, shifted its meaning to be “clean” gray water, playing a new and important role in mundane practices (see the examples of quotes in table 3 for new discursive meanings).

However, in the next four sections, we group the households and explore their more strategic patterns of practice realignment. These strategic realignments enacted four ontological states that we term embedded insecurity, discursive insecurity, acclimating security, and new embedded security.

\section{Embedded Insecurity}

During fieldwork, the first author took field notes on the frustration felt by a group of households who encountered many blocked practices in their strategic responses to the drought (see table 1, Embedded Insecurity). This occurred due to obdurate materiality that limited adjustments and the households' inability to attune their practices. For instance, 
Joanna and Michael were thwarted by material configurations imposed by renting and a landlord who resisted fixing a leaky faucet for over six months. Jane owned her home but found gray water practices, such as carrying heavy buckets, impossible given the limitations of her older body. Within these households, feeling secure was blocked by the material constraints imposed by renting or embodied limitations to conserving water. Thus, rather than materiality fixing security as in the past, now the obdurate materiality embeds insecurity for these households (see table 2, Embedded Insecurity).

These households discursively integrated the shared meaning of water conservation as a new and important part of being a good citizen. Households continued many of their basic everyday practices, such as showering and flushing the toilet, but limited water consumption. They transferred commonly embodied competencies-like turning off faucets, taking shorter showers, and flushing less regularly. For instance, Jane made simple changes altering how she showered:

There is a small bathroom that happens to be near the hot water cylinder and another small bathroom in our bedroom that's further from the hot water. So I just, instead of having my shower at the one closest to my bedroom, I just walk those extra couple of feet and go to the other one... I turn the tap on and the hot water comes straight away. Don't have to waste water waiting.

Informants reflected deeply across conventional meanings that were once implicit, such as meanings of clean and convenient. Jane also let her English-style garden die, seeing it now as “an extravagance that's useless.” Unlike some households that worked to save their gardens, Jane could not afford to invest in rainwater storage or endure the physical demands of hauling buckets to her garden.

Material and financial constraints limited opportunities for these households to enact new practical understandings. Joanna and Michael grew up in drought-prone rural areas using water tanks and easily returned to being citizens who shared in the sacrifice of saving water. They stopped practices like using a dishwasher and substituted washing their dishes by hand. 
Joanna liked using the least possible amount of water, although she was self-conscious about describing this new practice.

This sounds so stupid, [but] I try and play games with myself to see how little water I can use. So like when I wash up, I'll only put the smallest amount of water in the bottom, just enough to cover the cutlery or whatever, and wash with that. And then just turn it on just a little tiny bit to rinse it off, and turn it off again. And I mean, I only end up using about a quarter of a sink.

However, while they were skilled at conserving water and using less than the average singleperson household (as evidenced by their water bill), they often collected more gray water than they could use on their houseplants. They had to uncomfortably pour it down the drain.

These changes were not without other contradictions that sometimes disrupted their practical understandings and required micro-adjustments. These informants could not invest in new consumer durables nor build water-saving systems, but they tried to reduce water consumption by dropping routines or adopting new ones. They also made micro-adjustments to elements of existing routines, such as their embodiment, small material changes, and changes in meaning. For example, gray water took on a new meaning as valuable. Phoebe, also an apartment renter, found ways to use gray water to help reduce her anxiety: "all that water [collected from the shower] gets used, either it goes into the washing machine and then the rinse water goes onto the gardens. So I don’t feel so bad about that.” She used gray water to keep her vegetable garden alive, refusing to worry: “they say you shouldn’t use it for, say, lettuce just before you eat it, but I do.”

Overall, traditional homeowners have a greater sense of security than renters because owning a home gives people more material control over their future (Nettleton and Burrows 1998). Moreover, wider discourses on Australian homeownership encourage the move from renting to buying because renting is associated with instability and dependence (ColicPeisker and Johnson 2010). This means that renters already have great difficulty enacting self-sufficiency through homeownership. Although these households shared making 
sacrifices through water conservation, their embedded insecurity was amplified by the disruptive influence of the drought. Desiring greater self-sufficiency, Joanna stated, "Both of us would love to be able to install a tank. For home use purposes, just to connect it up to something.” Although frustrated, these households were resigned given the limits of obdurate materiality. These households reworked notions of being a good Australian into a less-thansatisfactory performance of everyday practice but were still sharing the sacrifice within existing material constraints.

\section{Discursive Insecurity}

A second group involved households with children or households continuing to maintain their gardens (see table 1, Discursive Insecurity). For these households, it was difficult to maintain routines, such as laundry and housework, because the realignment of practices using less water was unstable. Fragile practices were unstable and these households continued to feel insecure. Although these informants integrated new materials to conserve water, they did not return to a secure practical understanding when performing routines. Instead, bodies struggled to haul water, hosing was an entangled mess, and housework expanded. Recursive failed attempts to integrate practical and discursive understanding created feelings of discursive insecurity (see table 2, Discursive Insecurity).

For this reason, these informants were the most reflective, with many changes in practices leading to cascading opportunities for reflection. What is housework? What is a water-less garden? What is a beautiful garden with native plants? What is clean and what is dirty? What is order and what is disorder? Their practical understandings were pierced, and they engaged discursively reflecting upon old and new conventional meanings. As households questioned the meanings of existing practices, new discursive understandings arose. For instance, Julie was clearly thoughtful as she reevaluated standards for cleaning her 
bathtub. She debated the aesthetics and hygiene of an uncleansed bathtub where her grandchild would place his bare bottom. Although some cleaning practices can be waterless, a clean bathtub requires water.

While I could just leave the bath totally gross and full of dirt until we use it. There is a bit of a compromise between having a household that looks reasonable and not using the water. You might be in the situation where, I don't know, what you would doyou would dust the bath? It does need washing or something? It gets used by our grandchild so you do need to clean it sometimes.

Christine also rethought hygiene around flushing human waste. “I hope this doesn’t sound gross, but four of us get up, we use the toilet, bang, bang, bang, bang, and then we flush it.” Although seeing a stranger's urine was still socially unacceptable, within the privacy of their home, a shared family flush of the toilet was a new practice enacting a new convention of water conservation and reworking conventional understandings of hygiene. However, single individual flushes of fecal matter remained the norm.

Households contemplated many practices that were previously automatic and unreflective. A constant interplay existed between discursive and practical understandings within this lived condition of discursive insecurity. Through dropping practices, changing elements in existing practices, and adopting new practices, households tried to return to the once easy performance of domesticity. For these informants, however, many re-integrated practices were still fragile. Women bore much of the additional labor, such as doing a range of cleaning practices using less water, hauling gray water for reuse, and using materials that added burdens to producing domesticity.

For example, Christine's routines exemplify this interplay. She adopted the new practice of bailing family bath water for flushing toilets and gardening. This practice of hauling gray water required little more than a bucket and had few additional meanings other than conserving water. As an embodied competency, however, carrying water was hard labor — a five-gallon bucket of water weighs over 40 pounds. Laundry, once a practice at 
which she was skilled, was now unstable. As a case in point, during the interview, Christine heard water leaking from the nearby laundry. She had added plastic piping to her washer to divert water from the rinse cycle to the backyard. The fragility of this new practice was evident as the piping came loose and the interview stopped as we rushed to clean up the mess. As we mopped up the overflow, she expressed a new longing for a water-efficient machine. However, she could not afford the expense of replacing her washing machine. Thus, without significant investments in new materials, Christine’s routines have expanded to be more labor intensive, and new meanings of housework reflect this additional burden of doing her bit as an Australian: “The extra effort, they [my family] are not very good at. I will make the extra effort, just because I think, well, we live in the driest continent.” Similarly, for Hannah, the practice of doing laundry also changed from a mindless task to one that required vigilance. Hannah had to be home when doing her laundry since she used new rubber tubing running through a back door that had to be left open and unsecured.

Correspondingly, Amy did not return to the "bubble of inattention” around gardening practices because of fragile links between competencies, materials, and meanings. She was a passionate gardener who was trying to keep her beloved garden alive within the constraints of available materials and her limited physical abilities as a 70-year-old woman. Amy hired a plumber to divert her washing machine rinse cycle into her garden:

There is a problem with that because the water won't travel uphill unfortunately, so it only does a certain section of the garden. So we've got to watch that. That hasn't been perfected yet. It's just one extra thing. Actually, before that, we were actually lifting up the window and shoving a hose in and that was all sort of a bit time consuming and fiddly, but now it's being done correctly. It looks pretty awful out there. There are pipes and hoses lying around everywhere.

Amy's preferred conventional meaning of an aesthetically pleasing garden was thwarted by the "awful” looking jumble of new materials needed to maintain her garden. She uncomfortably endured this new fragile practice. 
This feeling of discursive insecurity meant that mateship was enacted through a sense of everyone sharing the burden; for these households the burden included this sense of insecurity. Hannah described the embodied sensation that "something about this whole thing [conserving water] feels a bit familiar.” When elaborating on this feeling, Hannah evoked the idea of mateship: "we all need one another; no man is an island. It's that sort of idea, I think, the shared responsibility type of thing, I think, as opposed to, 'Stuff everyone else. I'm looking after number one.”’ Although their practices were fragile, these households enacted mateship through stoically sharing sacrifices. But other households moved through this ontological state of discursive insecurity to achieve a return to greater trust and security in the world, albeit to varying degrees.

\section{Acclimating Security}

In contrast to those households experiencing discursive insecurity, a third group of households successfully reformed their practices, integrating rainwater systems to support important gardening practices (see table 1, Acclimating Security). These households reflected on the problem of maintaining a garden and then retooled to expand their water supply through investments in new materials and creating new rainwater management practices. We call this ontological state acclimating security because they were reestablishing greater sense of ease as their practices were stabilizing around new rainwater systems (see table 2, Acclimating Security). They eventually reduced their labor, returning to a new comfortable normality and practical understanding.

For this group of households, they felt the greatest insecurity within practices around gardening. Reflection shifted more narrowly to how to save their gardens by building and maintaining rain and gray water systems. Mastering water storage and management practices became necessary to return to the mindless groove of performing routines like cleaning and 
bathing but, most importantly, gardening. They transitioned through a stage of discursive insecurity as they learned new practices. They had to reflect on new conventional meanings such as, what are adequate or inadequate stores of water? What are the aesthetics of rainwater tanks in the garden? New competencies were needed to estimate water usage, predict weather and potential replenishment, and monitor storage.

Maurice inaccurately estimated that his garden needed a 2,000-liter rainwater tank, but normal watering would “empty it in a day.” Once he installed a 20,000-liter tank, he was "having fun” and feeling more secure that his garden would survive. But even after installing a 20,000-liter tank, Maurice carefully monitored his storage levels to avoid running out. He also became more competent at monitoring the weather and estimating the likelihood of his supply being replenished. "We are more aware of water, when it’s going to rain. So I'll look at the weather report and see we're going to have three days of showers this week, will it make a difference?”

We use Heidegger’s (1962) “ready-to-hand” terminology to conceptualize the comfort and ease households were beginning to experience with their new tools and practiced competencies (see table 2). Ready-to-hand is characterized as a form of skillful coping where practical activity is smooth; practitioners become aware of their embodied engagement with the tool within the ongoing experience of using it (Cappuccio and Wheeler 2010). We use the term to capture how these new tools were beginning to align to restore automaticity and enact new embodied practical understandings.

Installing new rainwater tanks meant some informants returned to earlier, more waterintensive gardening practices (although most continued some of the new drought-tolerant gardening). For example, Stacey’s insecurity originally stemmed from threats to her hobby gardening, which was the setting for important family practices such as dining alfresco, relaxing, and entertaining. Moving from a rural area to the city, Stacey enthusiastically 
shifted from the rural meaning of water scarcity to the urban meaning of abundance: "We're city people [now], so you just take it all for granted. It’s like switching on the ducted heating." Stacey reworked new materiality by installing rainwater tanks and gray water systems. She also returned to old practices enacting meanings of water as abundant, such as having two showers a day or using a water-hungry washing machine since the gray water could be reused on her beloved garden:

I have a top-loading machine which uses a lot of water. But I'm not prepared to buy a new one just for the sake of saving water. Because I then use that water on my garden because as you can see we have a very large garden which I refuse to let die. So that gray water goes all onto the garden.

These households were at various stages in the process of acclimating security. They were “keeping up appearances” through water conservation, but good appearances now included using a rain tank:

So we eventually had to unload them down in the other street and drag them up the back laneway, which was quite funny. But, that in general, everybody’s saying: "Oh tank, yeah." So there were various people around the streets saw these tanks, which you could hardly avoid them, and that generated quite a lot of interest in "Oh what are you doing? How are you putting the tanks in?” and so forth. (Richard)

Mateship still meant sharing sacrifice, but self-sufficiency was becoming more foregrounded through practices using independent water supplies. These households asserted their individual right to have a garden as long as they were able to do so without threatening social solidarity. For example, signs stating, “This house uses rainwater” were erected outside many households. This enabled households to express pride at their self-sufficiency but also helped avoid social conflict if neighbors felt their lawns were suspiciously green.

\section{New Embedded Security}

The fourth and final group of households created private water-provisioning systems, achieving partial and even complete independence from the urban water mains (see table 1, New Embedded Security). In short, they reworked new obdurate materiality that would 
support their routines and a return to feeling secure and safe. Some households used their financial resources to buy a sustainable apartment or build a sustainable home. Other households were skilled at renovating their homes. These households eventually more closely resembled the embedded security experienced before the drought, when practices were aligned. This fourth group of households built new systems supplying water, enabling them to return to stable practices, implicit conventions, and the bubble of inattention of embodied competencies. Due to the novel material configuration, these households struggled to move from an earlier stage of acclimating to a new embedded security over months and even years.

Like the households who were attuning practices, these informants adopted new practices around monitoring and maintaining their new systems. For rainwater tanks, they monitored water levels and followed weather forecasts. New practices for gray water systems included cleaning and maintenance, monitoring the water quality level, and ensuring only biodegradable materials went down gray water drains. But these new practices must be appropriated through learning new competencies and domesticated until their performance can be taken for granted (Illmonen 2001). We call these “attached practices” because considerable repetition is needed before they become automatic and unreflective.

These practices entailed discursive understanding, but this reflection now occurred around enacting more taken-for-granted conventions. These households no longer questioned whether gray water is clean enough to be used for the laundry or garden. They did debate on which source of gray water should be used, how much is used, and for which purposes? For instance, Neil's household shifted his laundry rinse diversion between waste and gray water, since his gray water system could not always handle the volume of water.

Neil spent eight years retooling his family home, carefully evaluating and experimenting with new materials. New competencies included constantly monitoring his systems to ensure that the gray water filters remained clean and did not overflow. Neil hired 
architects and plumbers for expertise on implementing his new systems, but they were unable to provide clear guidance with these unfamiliar technologies: "I suppose we are a bit of a laboratory in that respect because there is (sic) not that many of these [gray water] systems installed.”

New and old practices were stabilizing around reworking the new obdurate materiality, realigning around new meanings and enacted competencies, and developing over time. For example, Bridget and her husband bought their new apartment for its sustainability. Bridget stated: "I thought it was an important thing to do. And the easiest way for me to do it was to move in where somebody else had already put the structure in place.” Permanent water-saving devices were built into the household water system. Gray water from bathing was collected, treated to Class A water level (one level below drinking standards), and fed back into the toilet cisterns and washing machines upon demand. Rainwater storage provided water for Bridget's garden and a communal vegetable patch. But Bridget had to develop new conventional understandings, such as being careful about which soaps she used in her gray water system.

These households went through many cycles of practice alignment. They often were in an ontological state of unease, where practical understandings were disrupted and they engage in discursive understandings. Consider Veronica’s quote on cleaning dishes, which was but one domain where she engaged in the cycles of reflection needed to develop her totally mains-free house.

I did a pile of dishes in the sink, then after I completed that I measured how much water I had used in the sink and I filled it up to half full. Then I realized if I hand wash up, I save electricity, and I used slightly more water, but if I use the dishwasher I save a bit of water, but I used more electricity. So there is a trade-off. ...I then decided that I would wash up in my little sink, so now I wash up with less water.... I wash up once a day. Whereas in the past, I thought it was a bad practice to have dirty dishes around. And you should have them out of sight and you could wash up, and dry up, and put them away. That would be interpreted as being a good housewife. 
But achieving a materially embedded state of security was not without challenges given the new understandings and competencies required by these not-yet-conventional systems.

I heard this noise in the middle of the night... and there was little Jayden. He had woken up—-kids get sick all the time_-vomited in bed, and there he was about to try and vomit in the hand basin. So I said, "No! You can't vomit there. You have to vomit in the loo [toilet]." So I thought you really [have] got to be on the ball.... Everything you use in the bathroom you have got to be really careful about. You can't use a bar [of] soap. You've only got to use liquid soap.

Andrew's household was independent from the mains, except for less than 20 liters a day for cooking, drinking, and brushing teeth. Cycles of reflection span mulching the garden with free mulch, washing dishes by hand, using a low-flow showerhead, buying secondhand rainwater tanks, transitioning to efficient appliances, and employing rainwater tanks and gray water systems, to name but a few. Andrew articulated a return to a new normality for his household:

In terms of saving water, a lot of the decisions have been made and the thought has gone into it and we don't think day-to-day about it anymore. Our shower, for example, is supplied with rainwater, both the hot and the cold. And so we are not actually thinking about that at the point of turning the shower on.

Andrew's new system enabled his household to engage in practices that would be unthinkable for other informants in this study. He nurtured 20 fruit and nut trees and seasonal vegetables growing year round in his back garden with water he had ingeniously collected.

Informants who created independent systems supporting new complexes of practices using rain and gray water moved back to the greatest levels of new embedded security. Given their greater independence and sustainability, they achieved the greatest ontological state of security of all those interviewed. Mateship was enacted as individual autonomy and pride at being self-sufficient without threatening social solidarity. They made considerable investments to create these new practices rather than sharing sacrifices by conserving water.

\section{DISCUSSION}


This reseach highlights how security is co-constituted through the interplay among practical and discursive understandings and the material configuration of consumption. Through the lens of practice theory, we extend Gidden’s (1984) concept of ontological security by outlining five ontological states operating within the performance of stable and unstable practices. Figure 1 outlines the interaction between practical and discursive understandings and the anchoring of these understandings within materiality and constitutive rules. (Please note that this figure is an illustratrative snapshot of dynamic processes.)

\section{[Insert figure 1 here]}

At the center of figure 1 is the constitutive rule. A constitutive rule defines the nature of the activity (Swidler 2001). In this study, mateship was a contitutive rule of citizenship; egalitarian individualism was enacted in routines of shared sacrifice and independence that did not challenge social solidarity (see Table 2, last column). The ontological state is the existential sense of security or insecurity people have within the predictability or unpredictability of their routines (Giddens 1984). Figure 1 outlines the five ontological states that emerged in our findings — embedded security, embedded insecurity, discursive insecurity, acclimating security, and new embedded security—which are constituted within different interplays between practical and discursive understandings.

All households moved from a pre-drought state of embedded security to discursive insecurity across multiple attempts to re-stabilize many different routines. But a household's return to a secure state can be blocked by obdurate materiality and thus the unsatisfactory performance of practices intensifies insecurity (i.e., embedded insecurity). Alternatively, obdurate materiality can facilitate the smooth performance of routines and feelings of security (i.e., embedded security) or in the case of households who rebuilt new catchment systems creating new routines (i.e., new embedded security). Our context of household routines 
highlights both the possibility for rather quick adjustment (see the first eleven rows in Table 3), but also the very slow adjustments that span years as some households sought routines independent from urban mains. In the next five sections, we explore how our theorizing of these five ontological states helps deepen our understanding of past consumer research as well as offers potential directions for future research.

\section{Embedded Security}

A state of embedded security provides favorable conditions for aesthetic experiences such as those found in the study of taste regimes. Arsel and Bean $(2013,900)$ show how a taste regime "propagates a shared understanding of aesthetic order that shapes the ways people use objects and deploy the meanings associated with the material.” They argue that a central role of the taste regime is to permeate everyday practical knowledge in forms of doing, knowing, and relating to household objects. Specifically, they examine the taste regime advocated by the online forum Apartment Therapy.

Following our theorizing, we argue that taste regimes are successful because they are built within an existing framework of embedded security, where many tools are handled automatically, and when reflection occurs within taken-for-granted conventions, and practices remain stable (figure 1). At first blush, our reinterpretation seems at odds with Arsel and Bean’s (2013) demonstration of how Apartment Therapy problematizes the most mundane of activities, such as where to store the dish soap. Taste regimes problematize objects by continually questioning how they align within the regime's core meanings. This level of problematization exists, however, within frames that are familiar to the consumers. These kinds of problems exist in well-established conventional meanings of ordered domesticity, such as “Pillows on the Bed: How Many Are Too Many?” and “How Big Should a Rug Be?” Thus, the taste regimes advocated by Apartment Therapy are successful 
because they are built upon well-worn meanings of what constitutes a clean and tidy household and which arrangements are aesthetically pleasing.

Although a state of embedded security provides necessary scaffolding for consumers to feel comfortable with their aesthetic expertise within taste regimes (Arsel and Bean 2013; Maciel and Wallendorf forthcoming), the taken-for-granted nature of conventions does present obstacles. Future research might tackle the considerable challenges of how best to study the ontological states examined here. For example, the breaching methods of ethnomethodology discussed earlier might be revived or extended (Garfinkel 1967). Or the storehouse of methods from human-centered design organizations, like IDEO, also hold promise. Human-centered design builds innovative products based on insights about how people use, handle, and experience products. Innovative methods unearth the taken-forgranted and tacit aspects of consumer routines. For example, product designers generate better service encounters by experiencing emergency room services first-hand even embodying the experience of an injured person lying on a gurney (Brown 2009).

New methods might better unpack the intensity and duration of disruptions to routines. Shocks to ontological states may be triggered by smaller life events, such as the breaches highlighted by ethnomethodology. When practices are tied to constitutive rules, the trigger may also be relatively minor, such as when a fatshionista tears an irreplaceable garment and she is blocked from presenting herself as a stylish woman (Scaraboto and Fischer 2013, 1234). Rindfleisch, Burroughs, and Wong (2009) examine how large existential threats over the fear of death increase brand attachments among materialistic consumers. Does existential fear operate in similar or different ways to existential insecurity? Although not explored here, can intentional breaches of security promote productive changes? For example, a sports coach might create training challenges for athletes so performances unravel in order to develop robust competencies for recovery that are even 
stable under duress. Could these methods explore other threats to security, such as when disgust or anger disrupts a practice?

\section{Embedded Insecurity}

A state of embedded insecurity highlights how some material configurations are inherently unstable. It is during ontological states of insecurity that understandings are most accessible and embodied skills and tools are unwieldy. At the discursive level, reflection arises on what are often taken-for-granted and implicit conventional meanings in consumption (figure 1). Consumption in nature provides particularly clear insights into embedded insecurity. For example, surfing occurs within fragile and dynamic material configurations that often disrupt the romantic discourses that surfers seek (Canniford and Shankar 2013). These discourses provide an adaptable logic that consumers use to anchor surfing experiences within a virgin wilderness devoid of human influence.

Technological and economic features of surfers' experiences disrupt this logic. It is through contradictions and tensions within assemblages of nature that ontological insecurities emerge from betrayals among consumption resources that fail to work together. Betrayals, such as the encroachment of urban technologies on a picturesque beach, or the toxic materials used in surfing equipment, act to unsettle the practical routines of surfers. Canniford and Shankar (2013) also provide evidence that these discourses and practices become more subject to deliberation under such conditions (Swidler 1986). These force surfers to engage in 'purifying practices' to realign their practices within romantic ideals of nature.

Our research highlights the importance of restoring surfers' underlying sense of security if purifying practices are to be successful. Canniford and Shankar $(2013,1066)$ note that the purifying practices of masking and purging can "reproduce contradictions and social tensions" and at times surfers felt "slightly uncomfortable” within these practices. We 
conjecture that masking and purging practices are not fully successful because practical and discursive understandings did not align and security was not restored. Nevertheless, the purifying practice of redress, where consumers overcame contradictions, provides evidence of consumer moving out of the state of embedded insecurity. In particular, consumers innovating new ready-to-hand tools and reflecting on new conventions resonates with our findings on how consumers acclimate security.

Future research might explore the domain of health care as a context rife with medical routines where the use of technology embeds insecurity into medical practices. Women’s health care services employ painful and sometimes invasive practices, such as inserting a speculum into the vagina, causing some women to experience mild to strong anxiety with some consumers even forgoing the procedure (Domar 1986); “....no piece of the pelvic exam is as reviled as the vaginal speculum—-the cold, clicking, duck-billed apparatus that lifts and separates the vaginal walls so a near-stranger can peer inside” (Eveleth 2014). Embedded insecurity in overly medicalized procedures can send consumers fleeing to alternatives that feel more natural (Thompson 2005). Alternatives to vaginal speculums have reached the clinical market, but doctors have been unwilling to improve their skills, even when women have preferred the new clinical tool and clinicians have praised it (Eveleth 2014). Such new tools fail to be adopted despite discursive accounts that they are better and preferred. A switch to an approach aimed at more quickly developing physicians' embodied competencies might prove more promising and efficacious than offering discursive justifications.

\section{Discursive Insecurity}

Barnhart and Peñaloza’s (2013) study of how older people continue to consume when they can no longer consume independently provides insight into a life stage where discursive insecurity may be heightened. Their research demonstrates the fragile nature of the elderly 
consumers' ensemble and how the integration of caregivers is often a difficult process. When elders interpreted this assistance as a threat to their independence, all parties became frustrated or confused.

The authors note that age-related consumption may be a particularly uncomfortable process within the United States where "individualism, self-reliance, and independence are highly valued” (Barnhart and Peñaloza 2013, 1134). If independence is a constitutive rule of being an adult, then older consumers are faced with reworking this constitutive rule as they negotiate with their caregivers on what it means to be an older adult. Our research suggests that for this negotiation to be successful elderly consumers' need to feel secure within their practical and discursive understandings on what it means to be old and how this relates to their independence. Barnhart and Peñaloza’s (2013) research points to routines that were important for anchoring their elderly participants’ feelings of security within this logic of independence. For example, Abbie asserted her independence by barring her daughters from accompanying her in the doctor's examination room, Bea continued to climb ladders despite protests from her son-in-law, and Jane drove at night despite her son's assertions that she was at risk. Ironically, the very routines that enact security and independence for the elders trigger insecurity in their primary caregivers and families.

The interplay between practical and discursive understandings within a state of discursive insecurity is evident in the challenges faced by these older consumers. Each time an older person successfully performed a consumption practice, they revealed themselves as physically and cognitively competent and supported a discursive account of empowerment. When caregivers were patronizing, however, the reverse occurred and their sense of selfefficiency declined and feelings of personal dependency and deterioration increased (Barnhart and Peñaloza 2013). 
Future research might look into life stage transitions as an area where states of discursive insecurity are likely to be more prevalent. The introduction of a new baby into the family, integration of an immigrant into a new culture, and the transition of seniors into elderly care, all require consumers reworking conventional routines and they may feel insecure and their practices may be fragile. Consumers’ return to comforting routines depends on their ability to realign practices that may be contested and where obdurate material could either facilitate or impede practice realignment.

\section{Acclimating Security}

Past consumer research also demonstrates consumers acclimating security. As outlined in figure 1 , when consumers are acclimating security, new tools become increasingly automatic and meanings are more taken-for-granted. For example, Mick and Fournier (1998) examine how consumers experience stress and anxiety over the paradoxes of technology. Their consumers' coping strategies of accommodating, partnering, and managing may be reconceptualized as stabilizing routines that help acclimate security around new technologies. One informant, Harry, learns to adapt to a technology ill-suited to his body by practicing until he is comfortable. Another informant, Paul, views his car as his partner: "I think the more you kind of interact with a thing the better you understand it...” Donna works to master her computer: “I started getting comfortable and then I wasn’t afraid of them any more” (1998, 138). These coping strategies are acclimating security by stabilizing practical understanding to be a more effortless and smooth performance.

We can further illuminate Weinberger and Wallendorf's (2012) findings on the importance of Mardi Gras. New Orleans citizens’ existential security was shattered by the destructive force of Hurricane Katrina. These researchers demonstrated how the restoration of Mardi Gras re-anchored what it meant to be a New Orleanian. Mardi Gras allowed the 
community to re-acclimate their security through the practices of intracommunity gift giving. Shared practical understandings, such as catching gifts thrown by krewe members, making eye contact with masked riders, and the anticipation and patience of the spectators, all helped re-stablished New Orlean’s citizens' sense of community. In response to their question, "Why did Mardi Gras accomplish this when Christmas did not?” our research highlights the interplay between the constitutive rules of Mardi Gras as enacted by its celebrations. The Mardi Gras parade is an anchoring practice that enacts the constitutive rule of celebration. Being from New Orleans means a certain joie de vivre that is produced and reproduced in carnival practices. Mardi Gras as an annual celebration helped restore normality as practical and discursive understandings worked to re-establish a sense of security in the predictability of normal social life.

Little research examines the attunement of practices as they stabilize and as security is acclimated. But this may be a period when a new practice is most at risk of failing to be habituated. Research on attunement of practices might offer new insights for making more enduring changes to social practices. For example, freestyle skiing consists of a material configuration where the slightest misalignment can occur evoking peculiar and uneasy feelings. Woermann and Rokka’s (2015) explore the temporal experience of subtle misalignments within the practices make individuals aware of embodied competencies. We conjecture that productive change is more likely to occur when these moments persist and if these practices underpin or are connected to more important or anchoring practices, such as when pregnant women rethink daily routines using harsh chemicals in light of a constitutive rule that mothers protect their unborn children.

\section{New Embedded Security}


A state of new embedded security outlines how some material configurations stabilize. Our theorizing provides additional nuance in understanding the shift of the stigmatized practice of the tesettür to a normalized practice. As argued by Sandikci and Ger (2010), routinization enabled informants to be comfortable in their new practice. We conceptualize this new comfort as a shift from a state of insecurity embedded in veiling practices with drab and unfashionable accoutrements to a new state of embedded security in novel practices of fashionable scarfing, worn with self-assurance, and expressing new meanings.

Their research demonstrates how the life condition of modern Turkish womanhood is expressed in different doings and sayings. The comfort a woman feels towards the practice of veiling is tied to the language game she uses to evoke womanhood. For those middle class woman who see a modern Turkish female identity as tied to their Islamic faith, the routinization of veiling practices enacts a practical understanding of comfort and empowerment as Islamic piety is expressed. For those middle class woman who see a modern Turkish female identity as tied to a secular Turkey, the practice of uncovering enacts a practical understanding of comfort and empowerment through expressing modernity.

To veil or not to veil is contentious because it is a practice in which competing constitutive rules of being modern or faithful play out in the very bodies of these women. Veiling and not veiling are practices anchored to constitutive rules implicitly held by people. These constitutive rules function by people working strategically assuming that the rules apply to the practices at hand, even if they are unable to articulate this influence fully (Swidler 2001). These constitutive rules are frequently more available during unsettled times, such as during the simultaneous global spread and rise in controversy around the Islamic faith. Constitutive rules are also more available when people are engaging in unfamiliar practices, such as adopting a new practice (Sandikci and Ger 2010; Swidler 1986). Of course, 
Sandikci and Ger (2010) trace the broader cultural tensions playing out across rural/urban and local/global discourses within the rise of Islamism movements. Religious books were important in educating woman on a new interpretation of Islam. New meanings emerged as informants linked the veiling to more conventional meanings of aesthetics and freedom of choice.

Innovations, such as cell phones, might also be productively conceptualized and explored from the perspective of new embedded security. Cell phones are a material linked to countless daily routines, including communicating, planning social events in real time, capturing memories, doing work, finding restaurants, photographing, navigating, and playing games, to name but a few. As discussed earlier, the iPhone is successful because of the ease of developing embodied competencies already supported by product features, such as twofinger recognition and pinch-to-zoom, and more recent additions, such as three-dimensional touch. We might conjecture that ready-to-hand could be a useful concept in understanding the ease of achieving automaticity in the adoption of new products.

\section{CONCLUSION}

Routines are a ubiquitous part of life. Their taken-for-granted nature enables the smooth running of consumers' lives—until these routines go awry. Our research outlined how consumers adjust to these disruptions. Emerging from the findings were five ontological states that demonstrated how consumers rework their practical and discursive understandings that are anchored in materiality and constitutive rules. It is hoped that future research can build from this framework to develop further understanding into other ways ontological states are underpinned within consumer practices. 
This research was primarily based on interview data but supplemented with observational data. Given that practical understandings emerged as an important focus, future research might explore more of the corporeal aspects of this type of understanding. In particular, data collection that focuses on the senses and emotions of participants can help to further unpack the embodiment of informants’ practical understandings.

\section{[Data collection Information]}

The first author conducted all of the in-person fieldwork and interviews from January of 2007 until December 2008 as part of his doctoral dissertation. Data were discussed and analyzed iteratively on multiple occasions by both authors using informant interviews and the first author's field notes. 


\section{REFERENCES}

Allen, Douglas E. (2002), “Toward a Theory of Consumer Choice as Sociohistorically Shaped Practical Experience: The Fits-Like-a-Glove (FLAG) Framework,” Journal of Consumer Research, 28 (March), 515-32.

Arsel, Zeynep and Jonathan Bean (2013), “Taste Regimes and Market-Mediated Practice,” Journal of Consumer Research, 39 (February), 899-917.

Arsel, Zeynep and Craig J. Thompson (2011), “Demythologizing Consumption Practices: How Consumers Protect their Field-Dependent Identity Investments From Devaluing Marketplace Myths,” Journal of Consumer Research, 37 (February), 791-806.

Australian Bureau of Meteorology (2007), “Melbourne’s Driest on Record,” May 15, http://www.bom.gov.au/announcements/media_releases/vic.

Badcock, Blair (2000), "Home Ownership and the Illusion of Egalitarianism," in A History of European Housing in Australia, ed. Patrick Troy, Cambridge: Cambridge University Press.

Barnhart, Michelle and Lisa Peñaloza (2013), "Who are you Calling Old? Negotiating Old Age Identity in the Elderly Consumption Ensemble," Journal of Consumer Research, 39 (April), 1133-53.

“Big Dry Breaks Record” (2007), The Age, May 10.

Bourdieu, Pierre (1977), Outline of a Theory of Practice, Cambridge: Cambridge University Press.

(1984), Distinction: A Social Critique of the Judgment of Taste, Cambridge, MA: Harvard University Press.

Brown, Tim (2009), Change by Design, New York: HarperCollins.

Butera, Karina (2008), “'Neo-mateship’ in the $21^{\text {st }}$ Century,” Journal of Sociology, 44 (3), 265-81.

Canniford, Robin and Avi Shankar (2013) "Purifying Practices: How Consumers Assemble Romantic experiences of nature,” Journal of Consumer Research, 39(5), 1051-69.

Cappuccio, Massimiliano and Michael Wheeler (2010), "When the Twain Meet: Could the Study of Mind be a Meeting of Minds?" in Postanalytic and Metacontinental: Crossing Philosophical Divides. Continuum Studies in Philosophy, ed. Jack Reynolds, James Chase, and James Williams, London: Continuum, 124-44.

Cassell, Philip (1993), The Giddens Reader, Stanford, CA: Stanford University Press.

Colic-Peisker, Val and Guy Johnson (2010), "Security and the Anxiety of Homeownership: Perceptions of Middle-class Australians at Different Stages of their Housing Careers," Housing, Theory \& Society, 27 (4), 351-71. 
Dion, Delphine, Ouidade Sabri, and Valérie Guillard (2014), "Home Sweet Messy Home: Managing Symbolic Pollution,” Journal of Consumer Research, 41 (October), 565-89.

Domar, A.D. (1986), "Psychological Aspects of the Pelvic Exam: Individual Needs and Physician Involvement,” Women Health, 10 (4), 75-90.

“Drought Proof Dam Hits Record Low Level” (2007), The Age, May 10.

Dupuis, Ann and David Thorns (1998), "Home, Home Ownership and the Search for Ontological Security,” The Sociology Review, 46 (1), $24-47$.

Eveleth, Rose (2014), “Why No One Can Design a Better Speculum,” The Atlantic, November 7.

Garfinkel, Harold (1967), Studies in Ethnomethodology, Englewood Cliffs, NJ: Prentice-Hall.

Giddens, Anthony (1979), Central Problems in Social Theory: Action, Structure, and Contradiction in Social Analysis, Berkeley and Los Angeles: University of California Press.

(1984), The Constitution of Society: Outline of the Theory of Structuration, Berkeley, CA: University of California Press.

(1991), Modernity and Self-Identity: Self and Society in the Late Modern Age, Cambridge: Polity Press.

Heidegger, Martin (1962), Being and Time, translated by John Macquaire and Edward Robinson, New York: Harper \& Row.

Hill, Tim, Robin Canniford, and Joeri Mol (2014), “Non-Representational Marketing Theory," Marketing Theory, 14 (4), 377-94.

Illmonen, Kaj (2001), “Sociology, Consumption and Routine,” in Ordinary Consumption, ed. Jukka Groncow and Alan Warde, New York: Routledge, 9-24.

Kapferer, Bruce (2011), Legends of People, Myths of State, New York: Berghahn.

Kapferer, Bruce and Barry Morris (2006), "Nationalism and Neo-populism in Australia: Hansonism and the Politics of the New Right in Australia," in Neo-nationalism in Europe and Beyond: Perspectives from Social Anthropology, ed. Andre Gingrich and Marcus Banks, New York: Berghahn, 248-70.

Maciel, Andre F. and Melanie Wallendorf (2016), “Taste Engineering: An Extended Consumer Model of Cultural Competence Constitution,” Journal of Consumer Research, forthcoming.

McDonald, Matt (2010), "Lest We Forget: The Politics of Memory and Australian Military Intervention,” International Political Sociology, 4, 287-302. 
Mick, David Glen and Susan Fournier (1998), "Paradoxes of Technology: Consumer Cognizance, Emotions, and Coping Strategies,” Journal of Consumer Research, 25 (September), 123-43.

Nettleton, Sarah and Roger Burrows (1998), "Mortgage Debt, Insecure Homeownership and Health: An Exploratory Analysis,” Sociology of Health and Illness, 20 (June), 731-53.

Page, James S. (2002), “Is Mateship a Virtue?” Australian Journal of Social Issues, 37 (2), 193-200.

Phipps, Marcus and Jan Brace-Govan (2011), "From Right to Responsibility: Sustainable Change in Water Consumption,” Journal of Public Policy and Marketing, 30 (2), 203-19.

Polanyi, Michael (1966), The Tacit Dimension, Garden City, NY: Anchor Books.

Reckwitz, Andreas (2002), "Toward a Theory of Social Practices: A Development in Culturalist Theorizing,” European Journal of Social Theory, 5 (2), 243-63.

Rindfleisch, Aric, James E. Burroughs, and Nancy Wong (2009), “The Safety of Objects: Materialism, Existential Insecurity, and Brand Connection,” Journal of Consumer Research, 36 (June), 1-16.

Sandikci, Özlem and Güliz Ger (2010), "Veiling in Style: How Does a Stigmatized Practice Become Fashionable?” Journal of Consumer Research, 37 (June), 15-36.

Scaraboto, Daiane and Eileen Fischer (2013), "Frustrated Fatshionistas: An Institutional Theory Perspective on Consumer Quests for Greater Choice in Mainstream Marketing," Journal of Consumer Research, 39 (April), 1234-57.

Schatzki, Theodore R. (1996), Social Practices: A Wittgensteinian Approach to Human Activity and the Social, Cambridge: Cambridge University Press.

(1997), "Practices and Action: A Wittgensteinian Critique of Bourdieu and Giddens,” Philosophy of the Social Sciences, 27 (3), 283-308.

(2001), “Introduction: Practice Theory,” in The Practice Turn in

Contemporary Theory, ed. Theodore R. Schatzki, Karin Knorr Cetina, and Eike von Savigny, London: Routledge, 10-23.

(2002), The Site of the Social, University Park, PA: The Pennsylvania State University Press.

Schatzki, Theodore R., Karin K. Cetina, and Eike von Savigny (2001), The Practice Turn in Contemporary Theory, London: Routledge.

Schau, Hope J., Albert M. Muñiz, and Eric J. Arnould (2009), “How Brand Community Practices Create Value,” Journal of Marketing, 73 (September), 30-51.

Searle, John R. (1995), The Construction of Social Reality, New York: Free Press. 
Shove, Elizabeth (2003a), Comfort, Cleanliness and Convenience: The Social Organization of Normality, Oxford: Berg.

(2003b), "Converging Conventions of Comfort, Cleanliness and Convenience,” Journal of Consumer Policy, 26 (4), 395-418.

(2003c), "Users, Technologies and Expectations of Comfort, Cleanliness and Convenience,” Innovation: The European Journal of Social Science Research, 16 (2), 193-206.

Shove, Elisabeth, Mika Pantzar, and Matt Watson (2012), "The Dynamics of Social Practice: Everyday Life and How It Changes,” London, England: Sage.

Shove, Elizabeth and Alan Warde (2002), "Inconspicuous Consumption: The Sociology of Consumption, Lifestyles and the Environment," in Sociological Theory \& the Environment: Classical Foundations, Contemporary Insights, ed. R. Dunlap, Frederick Buttel, Peteriley Dickens, and August Gijswijt, Lanham: Rowman and Littlefield, 230-51.

Swidler, Ann (1986), “Culture in Action: Symbols and Strategies,” American Sociological Review, 51 (April), 273-86.

(2001), "What Anchors Cultural Practices," in The Practice Turn in Contemporary Theory, ed. Theodore R. Schatzki, Karin K. Cetina, and Eike von Savigny, London: Routledge, 83-101.

Tavan, Gwenda (2009), “Testing Times: The Problem of 'History' in the Howard Government's Australian Citizenship Test,” in Does History Matter? ed. Klauss Neumann and Gwenda Tavan, Canberra: ANU E Press, 125-44.

Thompson, Craig J. (1996), “Caring Consumers: Gendered Consumption Meanings and the Juggling Lifestyle,” Journal of Consumer Research, 22 (March), 388-407.

(2005), "Consumer Risk Perceptions in a Community of Reflexive Doubt," Journal of Consumer Research, 32 (September), 235-48.

Thomson, Mark (1998), Blokes and Sheds Book, Makers, Breakers, and Fixers, Australia: Harper Collins Publisher PTY.

Turner, Bryan S. and June Edmunds (2002), "The Distaste of Taste: Bourdieu, Cultural Capital and the Australian Postwar Elite,” Journal of Consumer Culture, 2 (2), 219-40.

Wear, Andrew (2015), "How Best-Practice Public Administration is Quietly Transforming Victoria,” Australian Journal of Public Administration, 74 (3), 370-80.

Weinberger, Michelle F. and Melanie Wallendorf (2012), "Intracommunity Gifting at the Intersection of Contemporary Moral and Market Economies," Journal of Consumer Research, 39 (1), 74-92. 
Wilk, Richard (2009), “The Edge of Agency: Routines, Habits, and Volition,” in Time and Rhythms of Everyday Life: New Agendas and Directions, ed. Elisabeth Shove, Frank Trentman, and Richard Wilk, New York: Berg.

Wittgenstein, Ludwig (1958), Philosophical Investigations, New York: Macmillan.

Woermann, Niklas and Joonas Rokka (2015), "Timeflow: How Consumption Practices Shape Consumers’ Temporal Experiences,” Journal of Consumer Research, 41 (April), 14861508.

Woermann, Niklas (forthcoming), "Back to the Roots! Methodological Situationalism and the Postmodern Lesson for Studying Tribes, Practices, and Assemblages,” Marketing Theory. 
TABLE 1-Households

\begin{tabular}{|c|c|c|}
\hline Interviewee & Household & Relevant Background \\
\hline \multicolumn{3}{|l|}{ Embedded Insecurity } \\
\hline $\begin{array}{l}\text { Michael, 31, Joanna, 25, } \\
\text { students }\end{array}$ & Rented apartment, 2 adults & Both grew up in the country \\
\hline Phoebe, 30, teacher & $\begin{array}{l}\text { Rented apartment with garden, } \\
1 \text { male and } 1 \text { female flat mate }\end{array}$ & Teacher, gardener \\
\hline Jane, 75 , retired & Owned house/garden, 1 adult & Grew up in the country \\
\hline \multicolumn{3}{|l|}{ Discursive Insecurity } \\
\hline Hannah, 62, counselor & $\begin{array}{l}\text { Owned apartment with garden, } \\
2 \text { adults }\end{array}$ & $\begin{array}{l}\text { Empty nester downsized } \\
\text { from family home, gardener }\end{array}$ \\
\hline Julie, 65, teacher & Owned house/garden, 2 adults & $\begin{array}{l}\text { Garden as recreation, } \\
\text { science teacher }\end{array}$ \\
\hline $\begin{array}{l}\text { Christine, 54, secondary } \\
\text { school teacher }\end{array}$ & $\begin{array}{l}\text { Owned house/garden, } 2 \\
\text { parents, } 2 \text { children }\end{array}$ & $\begin{array}{l}\text { Mother, teacher, family- } \\
\text { and community-oriented }\end{array}$ \\
\hline $\begin{array}{l}\text { Maria, 54, homemaker, } \\
\text { David, 55, self-employed }\end{array}$ & $\begin{array}{l}\text { Owned house/garden, } 2 \\
\text { parents, } 4 \text { adult children }\end{array}$ & Passionate gardeners \\
\hline Amy, 70, retired & Owned house/garden, 2 adults & Passionate gardener \\
\hline $\begin{array}{l}\text { Tania, 64, nurse, Jeff, 66, } \\
\text { academic }\end{array}$ & Owned house/garden, 2 adults & Passionate gardeners \\
\hline \multicolumn{3}{|l|}{ Acclimating Security } \\
\hline Richard, 54, academic & $\begin{array}{l}\text { Owned house/garden, } 2 \text { adults, } \\
4 \text { adult children with partners }\end{array}$ & $\begin{array}{l}\text { Passionate gardener, } \\
\text { medical science background }\end{array}$ \\
\hline Naomi, 55, homemaker & Owned house/garden, 2 adults & Passionate gardener \\
\hline $\begin{array}{l}\text { Gabrielle, 57, retail, Beau, } \\
\text { 58, pharmacist }\end{array}$ & $\begin{array}{l}\text { Owned house/garden, } 2 \\
\text { parents, } 1 \text { adult child }\end{array}$ & $\begin{array}{l}\text { Owned a sustainable } \\
\text { organic olive farm }\end{array}$ \\
\hline $\begin{array}{l}\text { Maurice, 54, lawyer, Kate, } \\
\text { 55, customer service }\end{array}$ & Owned house/garden, 2 adults & Passionate gardeners \\
\hline Stacey, 61, homemaker & $\begin{array}{l}\text { Owned house/garden, } 2 \text { adults, } \\
1 \text { adult child }\end{array}$ & Passionate gardener \\
\hline \multicolumn{3}{|l|}{ New Embedded Security } \\
\hline Neil, 49, public servant & $\begin{array}{l}\text { Owned house/garden, } 2 \\
\text { parents, } 1 \text { child }\end{array}$ & $\begin{array}{l}\text { Background in } \\
\text { environmental science }\end{array}$ \\
\hline Bridget, 56, academic & $\begin{array}{l}\text { Owned sustainable apartment } \\
\text { with garden, } 2 \text { people }\end{array}$ & $\begin{array}{l}\text { Grew up in the country, } \\
\text { downsizing }\end{array}$ \\
\hline Andrew, 47, consultant & $\begin{array}{l}\text { Owned house/garden, } 2 \\
\text { parents, } 2 \text { children }\end{array}$ & History of activism \\
\hline Veronica, 72, retired doctor & Owned house/garden, 1 adult & Downsized \\
\hline
\end{tabular}


Table 2-Ontological States of Security and Insecurity

\begin{tabular}{|c|c|c|c|c|c|}
\hline \multicolumn{6}{|c|}{ Table 2-Ontological States of Security and Insecurity } \\
\hline $\begin{array}{l}\text { Ontological } \\
\text { State }\end{array}$ & Type & Alignment & Practical Understanding & Discursive Understanding & Constitutive Rule \\
\hline $\begin{array}{l}\text { Embedded } \\
\text { Security } \\
\text { (before } \\
\text { drought) }\end{array}$ & $\begin{array}{l}\text { Aligned } \\
\text { practices }\end{array}$ & $\begin{array}{l}\text { Stable; practices } \\
\text { aligned } \\
\text { effortlessly with } \\
\text { obdurate } \\
\text { materiality }\end{array}$ & $\begin{array}{l}\text { Bubble of inattention, } \\
\text { embodied competencies } \\
\text { performed smoothly; tools } \\
\text { sentient extensions; tacit, } \\
\text { automatic }\end{array}$ & $\begin{array}{l}\text { Little reflection, and } \\
\text { conventional meanings are } \\
\text { implicit }\end{array}$ & $\begin{array}{l}\text { "Mateship” means a fair go } \\
\text { at homeownership; } \\
\text { maintenance practices } \\
\text { enact self-sufficiency; } \\
\text { pride }\end{array}$ \\
\hline $\begin{array}{l}\text { Discursive } \\
\text { Insecurity }\end{array}$ & $\begin{array}{l}\text { Fragile } \\
\text { practices }\end{array}$ & $\begin{array}{l}\text { Unstable; } \\
\text { practices are } \\
\text { misaligned; } \\
\text { recursive failed } \\
\text { attempts to align }\end{array}$ & $\begin{array}{l}\text { Disruption in embodied } \\
\text { competencies as practices } \\
\text { come apart; tools unwieldy; } \\
\text { frustrated }\end{array}$ & $\begin{array}{l}\text { Ongoing reflection across old } \\
\text { and new conventional } \\
\text { meanings; meanings are } \\
\text { explicit }\end{array}$ & $\begin{array}{l}\text { "Mateship” means sharing } \\
\text { sacrifices; stoicism in the } \\
\text { face of hardships }\end{array}$ \\
\hline $\begin{array}{l}\text { Acclimating } \\
\text { Security }\end{array}$ & $\begin{array}{l}\text { Attuned } \\
\text { practices }\end{array}$ & $\begin{array}{l}\text { Re-stabilizing; } \\
\text { new practices are } \\
\text { stabilizing }\end{array}$ & $\begin{array}{l}\text { Self-conscious competencies; } \\
\text { through repetition working to } \\
\text { restore automaticity and new } \\
\text { tools ready-to-hand }\end{array}$ & $\begin{array}{l}\text { Re-stabilizing meanings with } \\
\text { older conventions becoming } \\
\text { more implicit but still } \\
\text { reflection on new conventions }\end{array}$ & $\begin{array}{l}\text { "Mateship" means sharing } \\
\text { sacrifices, household may } \\
\text { do this differently as long } \\
\text { as social solidarity is } \\
\text { preserved }\end{array}$ \\
\hline $\begin{array}{l}\text { New } \\
\text { Embedded } \\
\text { Security }\end{array}$ & $\begin{array}{l}\text { Attached } \\
\text { practices }\end{array}$ & $\begin{array}{l}\text { Stable; new } \\
\text { practices } \\
\text { embedded into } \\
\text { new obdurate } \\
\text { materiality }\end{array}$ & $\begin{array}{l}\text { Returning to new practical } \\
\text { understanding and new } \\
\text { embodied competencies } \\
\text { smoothly performed; tools } \\
\text { more sentient extensions }\end{array}$ & $\begin{array}{l}\text { Little reflection and new } \\
\text { conventional meanings } \\
\text { increasingly becoming implicit }\end{array}$ & $\begin{array}{l}\text { "Mateship” means } \\
\text { individual autonomy to } \\
\text { achieve self-sufficiency yet } \\
\text { not threatening social } \\
\text { solidarity; pride }\end{array}$ \\
\hline
\end{tabular}




\begin{tabular}{|c|c|c|c|c|}
\hline \multicolumn{5}{|c|}{ TABLE 3-Practice Realignment } \\
\hline Practices & Competencies & Materials & Conventional Meanings & Examples of Quotes \\
\hline Brushing teeth & $\begin{array}{l}\text { Same skills, but now turn off } \\
\text { water while brushing }\end{array}$ & $\begin{array}{l}\text { Same materials, } \\
\text { reduced water }\end{array}$ & $\begin{array}{l}\text { Same meaning, just adding water } \\
\text { conservation }\end{array}$ & $\begin{array}{l}\text { Thinking about not leaving the tap running, turning the tap off when you clean } \\
\text { your teeth, like it's built in. I've always done that. I don't waste water when I } \\
\text { clean my teeth. (Stacey) }\end{array}$ \\
\hline Toilet use & Decreased flushing & $\begin{array}{l}\text { Brick in toilet } \\
\text { cistern, gray water }\end{array}$ & $\begin{array}{l}\text { Social acceptability of unflushed urine; } \\
\text { using gray water saved from showering }\end{array}$ & $\begin{array}{l}\text { I hope this doesn't sound gross, but four of us get up, we use the toilet, bang, } \\
\text { bang, bang, bang, and then we flush it. (Christine) }\end{array}$ \\
\hline $\begin{array}{l}\text { Using } \\
\text { dishwasher }\end{array}$ & $<$ Broken link $>$ & $<$ Broken link $>$ & $\begin{array}{l}\text { Hygienic dishes now linked to hand } \\
\text { washing }\end{array}$ & $\begin{array}{l}\text { We tend to the wash the dishes once a day, they sit on the sink. We don't have a } \\
\text { mechanical dishwasher, we have four manual dishwashers. (Andrew) }\end{array}$ \\
\hline $\begin{array}{l}\text { Hand-washing } \\
\text { dishes }\end{array}$ & $\begin{array}{l}\text { Less frequent, creating clean } \\
\text { dishes while conserving water }\end{array}$ & $\begin{array}{l}\text { Sink with dishes } \\
\text { piling up, reduced } \\
\text { water }\end{array}$ & $\begin{array}{l}\text { Cleanliness delayed, untidy and extra } \\
\text { labor traded for greater water } \\
\text { conservation; using gray water saved for } \\
\text { gardening practices }\end{array}$ & $\begin{array}{l}\text { I wash up once a day. Whereas in the past, I thought it was a bad practice to have } \\
\text { dirty dishes around. And you should have them out of sight and you could wash } \\
\text { up, and dry up, and put them away. That would be interpreted as being a good } \\
\text { housewife. (Veronica) }\end{array}$ \\
\hline $\begin{array}{l}\text { Household } \\
\text { cleaning }\end{array}$ & $\begin{array}{l}\text { Less frequent, same skills with } \\
\text { reduced water }\end{array}$ & $\begin{array}{l}\text { Bucket or bowl, } \\
\text { gray water, } \\
\text { garden-friendly } \\
\text { cleaning products }\end{array}$ & $\begin{array}{l}\text { Cleanliness delayed, acceptability of gray } \\
\text { water saved from showering and laundry }\end{array}$ & $\begin{array}{l}\text { It's gray water. It's not really dirty. If I'm cleaning the toilet or washing floors, } \\
\text { well then I can divert this connection outside so that the water actually does go } \\
\text { down the drain. But just soap suds. I use a washing powder that is garden } \\
\text { friendly. So far nothing's died yet, so hopefully. (Amy) }\end{array}$ \\
\hline Laundry & $\begin{array}{l}\text { Know-how to divert washing } \\
\text { rinse }\end{array}$ & $\begin{array}{l}\text { Rubber hoses, } \\
\text { garden-friendly } \\
\text { laundry soap }\end{array}$ & $\begin{array}{l}\text { Cleanliness extended by using clothing } \\
\text { longer, acceptability of gray water in } \\
\text { garden and cleaning }\end{array}$ & $\begin{array}{l}\text { And the washing machine water now goes out through a connection the plumber } \\
\text { put in... There is a problem with that because the water won't travel uphill } \\
\text { unfortunately, so it only does a certain section of the garden, so we've got to } \\
\text { watch that. That hasn't been perfected yet. It's just one extra thing. (Amy) }\end{array}$ \\
\hline $\begin{array}{l}\text { Showering and } \\
\text { bathing }\end{array}$ & $\begin{array}{l}\text { Using bucket to catch water and } \\
\text { embodied strength to haul water }\end{array}$ & Bucket & $\begin{array}{l}\text { Cleanliness shortened by truncated } \\
\text { bathing, acceptability of gray water in } \\
\text { cleaning and gardening practices }\end{array}$ & $\begin{array}{l}\text { (Whispering) It is soooo nice. I know that is wicked. It is sooo nice. Because you } \\
\text { are actually covered, it is not this miserable strain of water... the length of my } \\
\text { showers has also dropped. And we have a little timer in it that we flick over } \\
\text { when we have a shower (Christine). }\end{array}$ \\
\hline Lawn practices & $<$ Broken link $>$ & $<$ Broken link $>$ & $\begin{array}{l}\text { Brown lawn socially acceptable; some } \\
\text { new use of AstroTurf and native grasses }\end{array}$ & $\begin{array}{l}\text { So they've got a vast lawn because they're on a double block, a big lawn, and } \\
\text { they've got the sprinklers going. (David) We were so shocked. (Maria) }\end{array}$ \\
\hline $\begin{array}{l}\text { Gardening } \\
\text { practices }\end{array}$ & $\begin{array}{l}\text { Hauling gray water, growing } \\
\text { drought-tolerant plants }\end{array}$ & $\begin{array}{l}\text { Buckets, hoses, } \\
\text { mulch, gray } \\
\text { water, drought- } \\
\text { tolerant plants }\end{array}$ & $\begin{array}{l}\text { Important leisure activity to be preserved, } \\
\text { new aesthetics for different plants }\end{array}$ & $\begin{array}{l}\text { Yes I've certainly changed my approach to the garden. And what I have grown } \\
\text { and what I won't. Well I think I just can't use that water. I think harder about } \\
\text { whether I'll indulge myself and run the tap and do it the easier way or whether } \\
\text { I'll do it the harder annoying way. (Julie) }\end{array}$ \\
\hline $\begin{array}{l}\text { Home car } \\
\text { washing }\end{array}$ & $\begin{array}{l}<\text { Broken link }> \\
\text { (some spot washing) }\end{array}$ & $<$ Broken link $>$ & $\begin{array}{l}\text { Cleanliness less important; new practice } \\
\text { of automated car washing using gray } \\
\text { water }\end{array}$ & $\begin{array}{l}\text {...we have a car, we rarely wash it. I couldn't tell you the last time we did. ... If } \\
\text { we were to wash it we would take it to a car wash and do it there. (Michael) }\end{array}$ \\
\hline $\begin{array}{l}\text { Swimming } \\
\text { pools }\end{array}$ & $<$ Broken link $>$ & $<$ Broken link $>$ & $\begin{array}{l}\text { Home pool is a luxury; using public pools } \\
\text { or seaside is preferred practice }\end{array}$ & $\begin{array}{l}\text { Thank god we had some pretty sound idea because if we were trying to put in an } \\
\text { Olympic swimming pool and have a big flashy tennis court and pool parties } \\
\text { every night then there are issues about that. Something outrageous in a } \\
\text { consumptive sense. (Neil) }\end{array}$ \\
\hline $\begin{array}{l}\text { Building } \\
\text { rainwater } \\
\text { systems }\end{array}$ & $\begin{array}{l}\text { Monitoring and maintaining, } \\
\text { monitoring weather, allocating } \\
\text { water storage }\end{array}$ & $\begin{array}{l}\text { Rainwater tanks, } \\
\text { piping, pumps }\end{array}$ & $\begin{array}{l}\text { Social acceptability of rainwater tanks } \\
\text { and using rainwater; generating rainwater } \\
\text { for other household routines }\end{array}$ & $\begin{array}{l}\text { We are collecting (rain) water to have a supply of water.... I suppose we're still } \\
\text { probably using it in terms of it’s an emergency supply for when we're not } \\
\text { allowed to water the gardens at all and all our plants will die. And for us we'd } \\
\text { like to have a backup so all the plants won't die. (Maurice) }\end{array}$ \\
\hline $\begin{array}{l}\text { Building gray } \\
\text { water systems }\end{array}$ & $\begin{array}{l}\text { Monitoring and maintaining, } \\
\text { monitoring water quality, filters }\end{array}$ & $\begin{array}{l}\text { Gray water } \\
\text { systems }\end{array}$ & $\begin{array}{l}\text { Acceptability of reusing gray water; } \\
\text { generating gray water for other practices }\end{array}$ & You become like little water managers (Neil). \\
\hline
\end{tabular}


Figure 1-Ontological States of Security and Insecurity

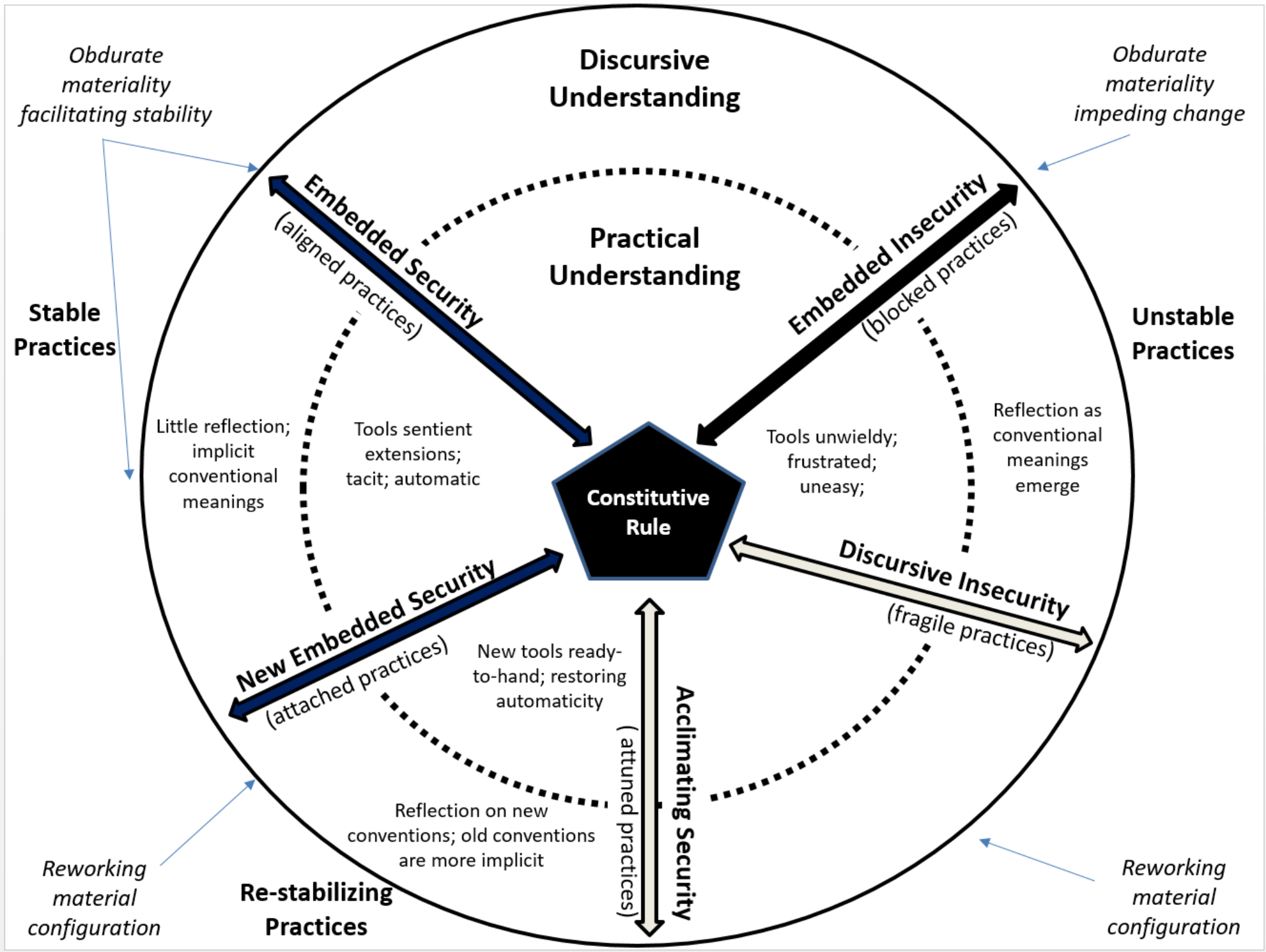




\section{THEORETICAL FOUNDATIONS}

2. Ontological State of Security

2. Discursive and Practical Consciousness

2. Practical Understandings

3. Untangling Forgotten Conventions and Embodied Understandings

3. Practical Understandings within Conditions of Life

3. Practical Understandings and Constitutive Rules

\section{RESEARCH PROCEDURES}

2. Research Context

2. Research Households and Data Collection Methods

2. Data Analysis

2. Mateship as a Constitutive Rule

1. ADJUSTING PRACTICES WITHIN ONTOLOGICAL STATES

2. Embedded Security

2. Ontological State of Insecurity Across all Households

2. Embedded Insecurity

2. Discursive Insecurity

2. Acclimating Security

2. New Embedded Security

1. DISCUSSION

2. Embedded Security

2. Embedded Insecurity

2. Discursive Insecurity

2. Acclimating Security

2. New Embedded Security 
1. CONCLUSION 